\title{
維持血液透析患者における膿尿および尿細菌培養所見の検討
}

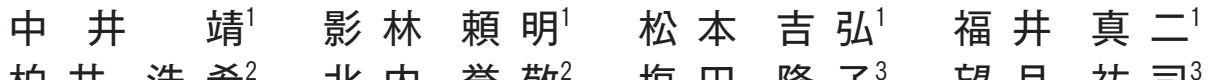 \\ 柏井浩希 ${ }^{2}$ 北内 誉敬 ${ }^{2}$ 塩田 隆子 ${ }^{3}$ 望月 祐 司 $^{3}$ \\ 三馬 省二1 \\ 1奈良県総合医療センター泌尿器科 2 柏井クリニック 3 済生会奈良病院泌尿器科
}

キーワード : 尿路感染, 膿尿, 尿培養, 無症候性血液透析患者

〈要旨〉

【目的】尿路感染症症状のない無症候性透析患者の尿所見を検討した.【方法】3か月以上血液透析を行っている患 者で明らかな尿路感染症状のない患者 54 名を対象とし, 尿沈椬および一般細菌培養の所見を検討した. 対象の平均 年齢は 65.1 歳, 平均透析期間は 46.4 月で, 糖尿病性腎症が原疾患の患者は 23 例であった.【結果】沈渣で白血球数 が $5 / \mathrm{HPF}$ 以上の膿尿患者は 20 例 $(37.0 \%)$ で，菌数が $10^{4} \times \mathrm{CFU} / \mathrm{mL}$ 以上の細菌尿症例は 19 例（35.2\%）であっ た. 膿尿症例 20 例のうち, 細菌尿は 9 例 $(45.0 \%)$ で認められた。膿尿のある患者と膿尿のない患者における細菌 尿の陽性率に差は認められなかつた $(\mathrm{p}=0.256) .38$ 例で 52 菌種が分離された. Staphylococcus 属が 12 例 $(23.0 \%)$ と最多で, Streptococcus agalactiae と Enterococcus faecalis が 8 例 (15.4\%), Escherichia coli は 5 例 (9.6\%) であった．また，多剤耐性菌は認められなかった【結語】透析患者の尿路感染症に対しては，てれらの所見を参考 にして, 治療方針を考慮するべきであると考えられた.

\section{Urinalysis and urinary bacterial culture in patients on maintenance hemodialysis}

Yasushi Nakai ${ }^{1}$, Yoriaki Kagebayashi ${ }^{1}$, Yoshihiro Matsumoto ${ }^{1}$, Shinji Fukui ${ }^{1}$, Hiroki Kashiwai ${ }^{2}$, Takanori Kitauchi $^{2}$, Takako Shiota ${ }^{3}$, Yuuji Mochizuki ${ }^{3}$, Shoji Samma ${ }^{1}$

${ }^{1}$ Department of Urology, Nara Prefecture Central Medical Center Nara Hospital, ${ }^{2}$ Kashiwai Clinic,

${ }^{3}$ Department of Urology, Saiseikai Nara Hospital

Key words : urinary tract infection, urinalysis, urinary bacterial culture, asymptomatic hemodialysis patients 〈Abstract〉

【Objectives】Urinary tract infection is one of the causes of mortality in hemodialysis patients. It is important to clarify aspects of urinalysis and urinary bacterial culture in such patients. This study was conducted to investigate urinalysis and urinary bacterial culture in patients on maintenance hemodialysis.【Methods】 The subjects were 33 men and 21 women with a mean duration of dialysis of $46.4 \pm 41.1$ months and mean age of $65.1 \pm 13.4$ years. The number of patients with diabetes mellitus was 23 . None of the patients had symptoms of urinary tract infection. We evaluated urinalysis, colony forming units and species of bacterium, and sensitivity to antibiotics. 【Results】 Pyuria was observed in 20 (37.0\%) out of 54 samples. Thirty-eight patients (70.4\%) showed bacteria in their urine. More than $10^{4} / \mathrm{mL}$ colony forming units were observed in 19 patients (35.2\%). Nine of 20 patients with pyuria and 10 of 34 patients without pyuria showed more than $10^{4} / \mathrm{mL}$ colony forming units. The difference in the rates of colony forming units of more than $10^{4} / \mathrm{mL}$ between patients with and without pyuria was not significant $(p=0.256)$. Fifty-two species of bacteria were detected in 38 patients. Staphyloccous spp. were detected in 12 patients (23.0\%). Streptococcus agalactiae and Enterococcus faecalis were each detected in 8 patients (15.4\%). Escherichia coli was detected in 5 patients (9.6\%). Gram-positive cocci constituted about $70 \%$ of the total in both men and women. There were no bacteria showing resistance to carbapenem antibiotics. No multi-

中井 靖 奈良県総合医療センター泌尿器科％ $731-0846$ 奈良県奈良市平松 1-30-1

Yasushi Nakai Tel : 0742-46-6001 Fax : 0742-46-6011 E-mail : nakaiyasusiuro@live.jp

〔受付日：2014 年 2 月 14 日, 受理日：2015 年 5 月 26 日〕 
drug-resistant bacterial species (e.g., methicillin-resistant Staphylococcus aureus and multi-drug resistant Pseudomonas aeruginosa) were detected.【Conclusion】A therapeutic strategy for urinary tract infection in patients on hemodialysis should be decided by considering these findings.

\section{緒言}

尿路感染症は，血液透析患者において罹患しやすい 重要な疾患の一つで, 死亡の原因ともなりうる Chavers らは, 感染症で入院した血液透析患者 12 万人 中に尿路感染症患者が 6,000 人 (5\%) で，うち 500 人 （8.5\%）が尿路感染症で死亡したと報告している。 こ のことから，尿路感染は維持透析患者において把握し ておくべき病態と考えられる，維持透析患者に尿路感 染が抢こりやすい原因として，（1）尿量減少により尿 路洗浄能が低下している，（2）免疫能の低下による易 感染性である，（3）糖尿病患者は易感染性であり，神 経因性膀胱も加わる，（4）尿量減少や代謝異常に伴う 尿路結石の合併が感染の原因となるなどが考えられて いる4).

1990 年前後には尿路感染症状のない維持透析患者 に対する尿沈渣検查，尿細菌培養についての報告が あったが, 2000 年以降は同様の報告は極めてまれで, また，細菌の種類や，抗生剂の感受性や耐性について の報告もほとんどない ${ }^{4 \sim 7)}$ ．近年，糖尿病患者の増加 や, 維持透析患者の生命予後の改善や, 抗生物質の使 用頻度の増加などを考慮すると， 1990 年から約 20 年 以上が経過した現在, 以前の結果と比較して, 多剂耐 性菌の増加, 菌種の変化などが予測される. 今回われ われは，尿路感染症状のない維持透析患者の尿沈渣検 查抢よび尿培養を行い，維持透析患者の尿路感染につ いて検討を行った.

\section{I．対象および方法}

当院を含む 3 施設において，3 3 拟上維持血液透 析中で，尿路感染症状のない末期腎不全患者に対し て, 本研究について説明を行い, 同意が得られた 54 例 （男 33 例，女 21 例）を対象とした。腎不全の原因疾患 は糖尿病性腎症患者が 23 例，囊胞性疾患が 4 例，腎炎 が 27 例であった。平均年齢は 65.1（土13.4）歳, 平均 透析期間は 46.4（土41.1） か月であった. 54 例中，泌 尿器疾患がある患者は 6 例 $(11.1 \%)$, 免疫抑制剂内服 患者は 2 例（3.7\%）であった，尿路にカテーテルが留 置されている患者や無尿の患者は除外した．採尿方法 は，男女ともに早朝中間尿を滅菌コップで採取し，滅
菌スピッッで持参してもらった．女性は外陰部清拭後 に採尿するように指示した，対象者はすべて午前の透 析患者とし， 3 時間以内に検体を提出し，尿沈渣検査 および尿培養を行った，尿検体を摚拌後二分し，一方 を $1,500 \mathrm{rpm}$ で 5 分間遠心分離し, 沈椬を 400 倍視野 で検鏡した. 白血球の個数は, 0 4 個/HPF, 5〜9個/ $\mathrm{HPF}, \quad 10 \sim 29$ 個/HPF，30 49 個/HPF，50 99 個/ $\mathrm{HPF}, 100$ 個以上/HPF と分類し，5個/HPF 以上を膿 尿とした。残りの尿検体で，一般細菌培養を行った。 菌数が $10^{4} \times \mathrm{CFU} / \mathrm{mL}$ 以上を細菌尿と定義した ${ }^{12)}$ 。分 離された菌種に対しては薬剤感受性を調べた。薬剤感 受性は自動菌種同定・薬剂感受性測定システムVitek 2 を用い, Clinical and Laboratory Standards Institute のブレークポイントに従った．尿中白血球数が細菌尿 の診断に有用であるかについては ROC 曲線を作製し 検討した。一日尿量は非透析日に各患者に測定記録を 依頼した。 な㧍, 本研究は奈良県総合医療センター（旧 奈良県立奈良病院）の倫理委員会の承認を得て行われ た.

有意差検定は Chi-square 検定, Mann-Whitney 検 定，およびロジスティック解析を用いた，有意水準は 両側 $5 \%$ とした.

\section{II. 結 果}

膿尿患者は 54 例中 20 例 $(37.0 \%)$ であった. 1 日尿 量は $300 \mathrm{~mL}$ 以上が 9 例 $(16.7 \%), 300 \mathrm{~mL}$ 以下が 45 (83.3\%)であった，尿中に細菌が検出された患者は 38 例（70.4\%）であり，菌数が $10^{4} \times \mathrm{CFU} / \mathrm{mL}$ 以上の細 菌尿は 19 例（35.2\%）に認められた。一方, 膿尿が認 められた 20 例中の 17 例（85.0\%）で尿中に細菌が検 出され，細菌尿は 9 例 $(45.0 \%$ ）に認められた。また, 膿尿のない 34 例中の 21 例（61.8\%）で尿中に細菌が 検出され，10 例（29.1\%）で細菌尿が認められた，尿 中に細菌が認められる患者は膿尿が認められた患者群 のほうが有意に多かったが $(\mathrm{p}=0.009)$, 細菌尿につい ては，有意な差は認められなかった（ $\mathrm{p}=0.256 ） （$ 表 1). 5 個/HPF 以上 $(n=5), 10$ 個/HPF 以上 $(n=10)$, 50 個/HPF 以上 $(n=1), 100$ 個/以上 $(n=4)$ の各症 例について細菌尿の有無につき ROC 曲線を作成した ところ，AUC 0.59 であった（図 1).

次に，膿尿㧍よび細菌尿が認められる患者における 


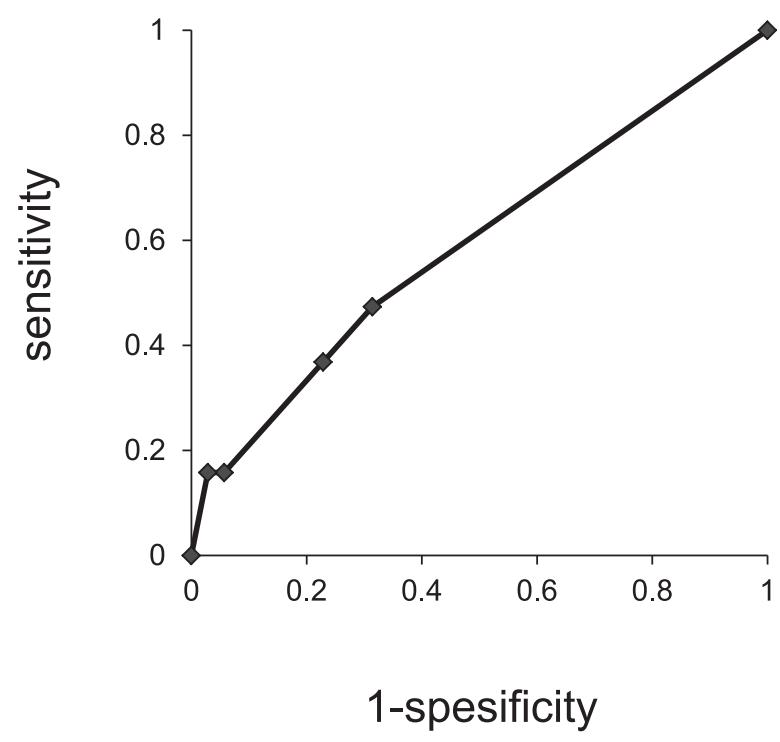

図 1 ROC plots of a stratified level of pyuria for bacteriuria. The area under the curve (AUC) was 0.59.

以下の因子について単変量解析により検討した。年 齢, 透析歴, 性別, 糖尿病の有無, 免疫抑制剂の有無, 尿路疾患の有無, 尿路感染症の既往, 1 日尿量が 300 $\mathrm{mL} /$ 日以上のいずれの因子においても，有意な差は認 められなかった（表 1).

菌種は, 38 例で 52 菌種が分離された（表 2). Staphylococcus 属が 12 例（23.0\%）と最多で, 次いで Streptococcus agalactiae と Enterococcus faecalis が 8 例 $(15.4 \%)$, Escherichia coli (E. coli) が 5 例 (9.6\%) であった。男性，女性ともにグラム陽性菌，特にグラ ム陽性球菌が約 70\%を占めていた。

薬剂感受性検査において，メチシリン耐性ブドウ球 菌, 多剂耐性緑膿菌, バンコマイシン耐性腸球菌, 多 剂耐性アシネバクター, 多剂耐性大腸菌などの多剂耐 性菌はいずれも認められなかった。 また，カルバペネ ム系抗生剤に耐性を示した菌も存在しなかった. 38例 のうち 20 例にクラリスロマイシン耐性菌が認められ, Enterococcus 属が認められた症例を除いた 31 例のう ち, 7 例でセファクロルおよび塩酸セフカペンピボキ シルに対する耐性が認められた。

\section{III. 考 察}

透析患者においては，膿尿が尿路感染のよい指標に はならないという報告 ${ }^{5,8,9)}$ や，逆に膿尿が尿路感染の 指標になるとの報告もあり ${ }^{10 \sim 12)}$, 一定の見解はない. $\mathrm{Vij} ら^{12)}$ は, 尿中白血球数を 5 個/HPF 以上, 10 個/ $\mathrm{HPF}$ 以上, 50 個/HPF 以上, 100 個/以上の分類で尿 路感染の ROC 曲線を作成したところ, $\mathrm{AUC}=0.73$ と
なり膿尿が維持透析患者の尿路感染の指標になると述 べている.今回のわれわれの検討における AUCは 0.59 であり, 透析患者における膿尿は細菌尿の指標と ならない結果であった. 尿路感染症の診断は一般的に は, 細菌尿に何らかの症状や所見を加えて総合的に判 断するものであるため, 透析患者において, 膿尿の有 無は尿路感染症の診断には有用ではないと考えられ た．膿尿の意義において報告により差異がある原因と しては尿量のばらつきが考えられる。末期腎不全患者 では, 腎障害や膀胱などの粘膜異常などから感染とは 無関係な白血球塊が形成されること ${ }^{11)}$ ，尿量が少なく なることにより膿尿を示しやすくなること委などの理 由から, 透析患者の尿は感染がない状態でも膿尿を呈 することが多くなる：この現象は尿量が減少すればさ らにおこりやすくなると考えられる．石原ら ${ }^{6)}$ は膿尿 に関して，尿量による分析を行い，尿量が $400 \mathrm{~mL} /$ 日 以下において, 膿尿患者が増加して, 尿量が減少すれ ば膿尿を示しやすくなることを報告している，さら に, Mortazavi ら ${ }^{11)}$ は尿量 $300 \mathrm{~mL} /$ 日以上の透析患者 においては, 膿尿は尿路感染の指標となると報告して いる.このように 1 日尿量が 300 から $400 \mathrm{~mL} /$ 日以上 の透析患者では膿尿が尿路感染の指標になる可能性が 示されている. 今回のわれわれの対象群は, 尿量 300 $\mathrm{mL} /$ 日以上の患者が 9 例 $(16.7 \%)$ と少なかったこと が, 膿尿が尿路感染の指標にならない結果につながっ た可能性が考えられた。

透析患者における尿細菌培養で検出された菌種につ いての報告は少ない. 石原ら ${ }^{7)}$ は透析患者における尿 培養の菌種について, 一般の尿路感染で検出される傾 向と異なり，E. coli をはじめとするグラム陰性菌より もグラム陽性菌の検出頻度が高かったと報告してお り, グラム陽性球菌が全体の $2 / 3$ を占めたと報告して いる.われわれの今回の検討においても同様の結果と なった。すなわち, 約 $70 \%$ がグラム陽性球菌であり, E. coli の割合は少なかった. 1995 年の石原らの報告7) から約 20 年が経過した現在においても菌種に変化は なく，これらの所見は透析患者における特徴である可 能性が考えられた.

Meiland $ら^{13)}$ はCKDの stage 別にE. coli 感染につ いて検討しているが, 腎機能が低下することにより E. coli の感染が増加することはないと報告している. 以上より, 透析患者では, グラム陽性球菌が増殖しゃ すい環境が存在し, E. coli 感染については非腎機能低 下患者と変わらない状態であると考えられる。透析患 者における尿路感染に対する抗生剤の選択において は, グラム陽性球菌感染の頻度が高いことを考慮すべ 
表 1 Univariate analysis of factors to predict bacteriuria and pyuria

\begin{tabular}{lccc}
\hline & \multicolumn{3}{c}{ Univariate analysis } \\
\cline { 2 - 4 } & Odds ratio & $95 \% \mathrm{IC}$ & $p$-value \\
\hline Age $(\geq 65$ years $/<65$ years $)$ & 1.029 & $0.974-1.087$ & 0.305 \\
HD duration $(\geq 40$ months $<40$ months $)$ & 1.016 & $0.989-1.044$ & 0.246 \\
Sex $($ Male vs. Female $)$ & 0.541 & $0.105-2.784$ & 0.462 \\
Diabetes mellitus & 1.208 & $0.137-4.606$ & 0.782 \\
Immunosuppressant & 0.615 & $0.018-21.015$ & 0.366 \\
Urologic disease & 2.291 & $0.380-13.826$ & 0.340 \\
Past history of urinary tract infection & 2.980 & $0.316-28.077$ & 0.462 \\
Urine volume/day $(\geq 300 \mathrm{~mL} /<300 \mathrm{~mL})$ & 0.517 & $0.096-2.796$ & 0.442 \\
\hline
\end{tabular}

HD : hemodialysis

表 2 Isolated bacterial species in urine samples

\begin{tabular}{lccc}
\hline & $\begin{array}{c}\text { Total } \\
\mathrm{n}=52\end{array}$ & $\begin{array}{c}\text { Male } \\
\mathrm{n}=31\end{array}$ & $\begin{array}{c}\text { Female } \\
\mathrm{n}=21\end{array}$ \\
\hline Staphylococcus spp. & 12 & 6 & 6 \\
Staphylococcus aureus & 2 & 1 & 1 \\
Streptococcus agalactiae & 8 & 6 & 2 \\
(-streptococcus & 3 & 2 & 1 \\
Bacillus sp. & 1 & 1 & 0 \\
Enterococcus faecalis & 8 & 4 & 4 \\
Enterococcus spp. & 4 & 3 & 1 \\
\hline Gram positive bacterium (\%) & $38(73)$ & $23(74)$ & $15(71)$ \\
\hline \hline Escherichia coli & 5 & 2 & 3 \\
Klebsiella sp. & 1 & 0 & 1 \\
Citrobacter sp. & 1 & 1 & 0 \\
Morganella morganii & 1 & 1 & 0 \\
Pseudomonas aeruginosa & 1 & 1 & 0 \\
Pseudomonas spp. & 2 & 2 & 0 \\
Haemophillus parainfluenzae & 1 & 0 & 1 \\
Other gram negative rods & 2 & 1 & 1 \\
\hline Gram negative bacterium (\%) & $14(27)$ & $8(26)$ & $6(29)$ \\
\hline
\end{tabular}

きであると思われた。なお，本研究においては，尿量 の少ない患者が多く，2 種類以上の細菌が同定されて いる患者が認められた。これは，雑菌の混入を考慮す べき症例と考えられ，正確な維持透析患者の尿細菌培 養を表していない可能性があるが, この点は本研究の 限界と考えられる.

非透析糖尿病患者においては，感染防御能の低下の みならず，末梢神経障害による神経因性膀胱，カテー テルの使用などの原因により無症候性の細菌尿が健常 人と比較して多くなると報告されている ${ }^{14,15)}$. しかし, 透析患者における無症候性の細菌尿が糖尿病患者に多 く認められるという報告は，われわれが調べた限りで は認められなかった，石原ら ${ }^{6)}$ は，無症候性の透析患 者において, 糖尿病群と非糖尿病群では尿路感染にお いて差が認められなかったと報告しており，今回のわ れわれの検討においても, この 2 群に差は認められず, 透析患者における尿量の減少などが, より無症候性細
菌尿の出現因子である可能性が示唆された.

薬剂感受性については, クラリスロマイシン耐性菌 が多く認められ，また第一世代経口セフェムや第三世 代経口セフェムに対する耐性菌も多数認められた。こ のことは, 透析患者への上気道感染や微熱などに対し て，経口セフェム剤やクラリスロマイシンの安易な投 与が行われている可能性が示唆されるが，今回の対象 の患者に対して過去の抗生剤投与については検討して いない.この点は, 今後の課題と考えられた. 今回の 尿培養, 薬剤感受性検査においては, メチシリン耐性 ブドウ球菌や多剂耐性緑膿菌などの多剂耐性菌は認め られず，また広域なスペクトラムをもつカルバペネム 系抗生剂に耐性を示した菌種は存在しなかった。 以上 をまとめると, 透析患者における尿路感染症において は，（1）グラム陽性球菌が多い，（2）いわゆる多剤耐 性菌は少ない,（3）複数の抗生剂に耐性を示すことが あるが，カルバペネム系など抗生剤には感受性が高い 
ことが示された. したがって，その治療はこれらの点 を考慮した抗生剤選択に基づいて進めることが，より 的確な抗生剤選択につながる可能性が示唆された.

尿培養検査を行った透析患者について，その後の尿 路感染症発症や, 発症時の起因菌について検討した報 告はない. しかし，透析患者において尿路感染症は死 因となる重要な疾患であり，尿路に常在する細菌が原 因となる可能性がある。透析患者の尿培養所見は尿路 感染症を発症した際の, 有用な情報となる可能性があ る.

\section{結語}

無症候性の維持血液透析患者における，膿尿，尿培 養所見について検討した。膿尿は尿路感染の指標とは ならず，菌種はグラム陽性球菌が $70 \%$ を占めた。経口 セフェム剤, クラリスロマイシンに耐性を示す細菌が 多かったが，メチシリン耐性黄色ブドウ球菌，多剂耐 性緑膿菌などの多剤耐性菌は認められなかった。

\section{文献}

1) Lees JA, Falk RM, Stone WJ, McDougal WS. Pyocystis, pyonephrosis and perinephric abscess in end stage renal disease. J Urol 1985; 134: 716-9.

2) Raymond R. Symptomatic Urinary tract infections in patients on maintenance hemodialysis. Nephron 1984; 37: 82-4.

3) Chavers BM, Solid CA, Gilbertson DT, Collins AJ. Infection-related hospitalization rates in pediatric versus adult patients with end-stage renal disease in the United States. J Am Soc Nephrol 2007; 18: 9529.

4) Chaudhry A, Stone W, Breyer JA. Occurrence of pyuria and bacteriuria in asymptomatic hemodialysis patients. Am J Kidney Dis 1993; 21: 180-3.
5) Eisinger RP, Asghar F, Kolasa C, Weinstein MP. Does pyuria indicate infection in asymptomatic dialysis patients? Clin Nephrol 1997; 47: 50-1.

6）石原哲, 小林覚, 前田真一, 他. 血液透析患者の膿尿 細菌尿 1. 膿尿・細菌尿の頻度について．透析会誌 1991；24：1291-5.

7）石原哲, 小林覚, 前田真一, 他. 血液透析患者の膿尿 細菌尿 2. 分離菌腫について。透析会誌 1995；28： 31-7.

8) Saitoh H, Nakamura K, Hida M, Satoh T. Urinary tract infection in oliguric patients with chronic renal failure. J Urol 1985; 133: 990-3.

9) Hyodo T, Yoshida K, Sakai T, Baba S. Asymptomatic hyperleukocyturia in hemodialysis patients analyzed by the automated urinary flow cytometer. Ther Apher Dial 2005; 9: 402-6.

10) Cabaluna CC, Gary NE, Eisinger RP. Urinalysis in patients on chronic hemodialysis. Urology 1977; 10: $103-4$.

11) Mortazavi M, Seyrafian S, Shahidi S, Abadpour Z, Shahbazi F. Pyuria as a screening test for detection of urinary tract infection in patients on long-term hemodialysis. Iran J Kidney Dis 2011； 5: 50-2.

12) Vij R, Nataraj S, Peixoto AJ. Diagnostic utility of urianalysis in detecting urinary tract infection in hemodialysis patients. Nephron Clin Pract 2009; 113: c281-5.

13) Meiland R, Stolk R, Geerlings S, et al. Association between Escherichia coli bacteriuria and renal function in women. Arch Intern Med 2007; 167: 253-7.

14) Stapleton A. Urinary tract infections in patients with diabetes. Am J Med 2002; 113: 80-4.

15) Karunajeewa H, McGechie D, Stuccio G, Stingemore N, Davis WA, Davis TM. Asymptomatic bacteriuria as a predictor of subsequent hospitalisation with urinary tract infection in diabetic adults: The Fremantle Diabetes Study. Diabetologia 2005; 48: 1288-91. 